\title{
Water Use in Sugar and Ethanol Industry in the State of São Paulo (Southeast Brazil)
}

\author{
Luiz A. Martinelli ${ }^{1}$, Solange Filoso ${ }^{2}$, Cecilia de Barros Aranha ${ }^{3}$, Silvio F. B. Ferraz ${ }^{4}$, \\ Tatiana M. B. Andrade ${ }^{1}$, Elizabethe de C. Ravagnani ${ }^{1}$, Luciana Della Coletta ${ }^{1}$, \\ Plinio Barbosa de Camargo ${ }^{1}$ \\ ${ }^{1}$ CENA-USP, Piracicaba, Brazil \\ ${ }^{2}$ Chesapeake Biological Laboratory, University of Maryland Center for Environmental Science, \\ Solomons, USA \\ ${ }^{3}$ Departamento de Águas e Energia Elétrica do Estado de São Paulo, Piracicaba, Brazil \\ ${ }^{4}$ Departamento de Ciências Florestais, ESALQ-USP, Piracicaba, Brazil \\ Email: martinelli@cena.usp.br
}

Received February 27, 2013; revised March 28, 2013; accepted May 12, 2013

Copyright (C) 2013 Luiz A. Martinelli et al. This is an open access article distributed under the Creative Commons Attribution License, which permits unrestricted use, distribution, and reproduction in any medium, provided the original work is properly cited.

\begin{abstract}
Brazil is the largest producer of ethanol from sugarcane in the world. While the ethanol industry is economically important to Brazil for several reasons, it also has a significant impact on the environment. Here we analyze the water consumptive use in the transformation of the feedstock (sugarcane) into ethanol and the impact of industrial byproduct effluents on water resources of the state of São Paulo, Brazil. Our estimates indicated that in the 2007-2008 harvest, 700 million $\mathrm{m}^{3}$ was withdrawn mainly from rivers and streams by 140 mills, and of this total 440 million $\mathrm{m}^{3}$ was consumed which yielded a water use of approximately $1.53 \mathrm{~m}^{3} \cdot$ water $\cdot \mathrm{ton}^{-1}$ sugarcane or approximately $18 \mathrm{~L} \cdot \mathrm{water} \cdot \mathrm{L}^{-1} \mathrm{ethanol}$. At the same time, a total of 120 million $\mathrm{m}^{3}$ of vinasse by-product was produced in the state, equivalent to an organic load of approximately 3 billion $\mathrm{kg} \cdot \mathrm{BOD}$ during the harvest season or approximately 8 million $\mathrm{kg} \cdot \mathrm{BOD} \cdot \mathrm{d}^{-1}$. Although the water used by sugarcane mills has decreased in recent decades, it is still possible to further decrease the amount of water used by ethanol production. This would decrease the pressure on 1st order streams of the state from which most water is withdrawn. In addition, the enormous volume of vinasse production must be reduced because it exerts constant pressure on aquatic ecosystems, soil and groundwater due to the constant increase in the potassium (K) concentration in areas where it is used as a fertilizer.
\end{abstract}

Keywords: Sugarcane; Ethanol; Vinasse; Water Use; Water Resources; Rivers; Brazil

\section{Introduction}

The global production of biofuels has increased exponentially in recent years for several reasons $[1,2]$. Efforts to reduce the use of fossil fuel for energy production are presently one of the leading forces behind this increase as the burning of fossil fuel is considered the main cause for increasing $\mathrm{CO}_{2}$ concentrations in the atmosphere, and thus, for global warming [3]. In addition, security concerns continue to play a very important role since many of the main fossil fuel producing countries in the world are considered politically volatile. In the developing world, the production of liquid biofuel is also seen as a means to promote economic growth [4], rural development [5], and new business opportunities for entrepreneurs [1]. Therefore, biofuel production has been grow- ing in many countries of the developing world.

Sugarcane ethanol is especially important to developing countries of the tropics and subtropics as the sugarcane crop offers one of the most cost-effective renewable energy sources that are readily available. Sugarcane is a perennial crop harvested on an annual cycle, with up to six cycles before re-planting. Consequently, production costs are tremendously reduced as there is only a short fallow between ploughing out the old cane and re-planting. In addition, sugarcane is a highly flexible resource, offering an alternative for production of food, feed, fiber and energy. Such flexibility is valuable in the developing world where fluctuations in commodity prices and weather conditions can cause severe economic hardships.

Presently, Brazil and the USA are the world's leading liquid biofuel producers [2], with Brazil producing etha- 
nol from sugarcane, and the USA producing ethanol from corn [6]. In both countries, ethanol production has been promoted as the alternative fuel of choice. However, despite all the economic and environmental benefits associated with liquid biofuel production, impacts are progressively more visible.

Sugarcane ethanol is a highly efficient converter of solar energy and has the highest energy-to-volume ratio of all energy crops [7] with relatively low nitrogen $(\mathrm{N})$ fertilizer application rates [8]. Moreover, sugarcane is an energetically favorable feedstock and the avoided emissions of green house gases associated with its production and use has been estimated to be approximately $2100 \mathrm{~kg}$ $\mathrm{CO}_{2}$-eq $\mathrm{m}^{-3}$ ethanol [9]. Even when estimates of energy balance for sugarcane ethanol are obtained through life cycle analysis, where the energy balance is expressed in terms of energy input:output, the results are usually more positive than negative, as shown in different studies 1:0.5 [10], 1:1.5 [11], 1:1.8 [12]; 1:3.7 [13] up to 1:9.3 [9]. However, unless some of the key environmental impacts which result from widely used agricultural practices and industrial processes for the production of sugarcane ethanol are addressed [8], the advantages of this alternative biofuel may not be as enticing in an economic market that is progressively more environmentally friendly.

In Brazil, sugarcane covered an area of a little more than 2 million ha in 1975, reaching approximately 9 million ha in 2010, representing an average growth of 0.2 million ha per year during this period. Such expansion is unprecedented, and it is imperative that excessive impacts such as on water quantity as well as quality [14] are properly investigated so solutions can be determined and the negative impacts minimized while benefits are maximized.

Basically, there are two types of water used to produce ethanol. The first is the water used to produce the feedstock (sugarcane), and the second is the water used to transform the feedstock into ethanol. The sum of these two types of water use is called the "water footprint" e.g. $[15,16]$, which accounts for the water evapo-transpired by the crop, also known as "green water", and the surface or ground waters, known as "blue water", used to irrigate feedstock or in the industrial process [17]. Several estimates for the water footprint of sugarcane in Brazil are available in the scientific literature e.g. [16,18-21]. However, information about water use in the production of ethanol from sugarcane during the industrial process is limited.

In the present study, we evaluate the water used in the industrial process by the sugarcane industry and evaluate potential threats to water resources by industrial effluents produced by mills operating in the state of São Paulo (henceforth referred to as São Paulo), the main ethanol producing region in Brazil.

\section{Water Use and Liquid Effluents Produced by the Sugarcane-Ethanol Industry}

Water use associated with the sugarcane industry varies according to the type of mill. The first type of mill produces only sugar, the second type produces only ethanol, and the third produces both. According to a survey made by CONAB [22], 75\% mills in São Paulo produce sugar and ethanol, $21 \%$ produce only ethanol, and the remainder only sugar.

In terms of amount of sugarcane harvested (in tons), $90 \%$ is used in mills producing sugar and ethanol, $7 \%$ in mills that produce only ethanol, and $3 \%$ in mills that produce only sugar. Also, mills that produce only sugar use a larger volume of water per ton of sugar cane than the other mill types [23]. More specifically, mills producing only ethanol or both use $50 \%$ and $70 \%$ less water, respectively, than mills producing only sugar. In all cases, water is used in the following proportions: $36 \%$ is used to wash sugarcane stems prior to fermentation, $27 \%$ is used in the fermentation, and nearly $27 \%$ in the distillation process [23]. Finally, $10 \%$ is used in additional processes common to both ethanol and sugar production.

According to a small survey conducted a few years ago about water use by the sugarcane industry in São Paulo [24] water withdraws have decreased from approximately $15 \mathrm{~m}^{3} \cdot \operatorname{ton}^{-1}$ of sugarcane processed in the $1970 \mathrm{~s}$ to $5 \mathrm{~m}^{3} \cdot \operatorname{ton}^{-1}$ in the $1990 \mathrm{~s}$, and then to less than 2 $\mathrm{m}^{3} \cdot \operatorname{ton}^{-1}$ in the present decade. However, despite improvements in terms of quantity of water used, the water withdrawn that is not evaporated in the industrial process is substantially altered during use [19] and not properly treated before returning to the watersheds. For instance, the water used to wash sugarcane stems ends up with high concentrations of solids and a BOD varying from 200 to $500 \mathrm{mg} \cdot \mathrm{L}^{-1}$. This effluent is then either recycled in the industrial process phase, or is mixed with other effluents to be used in the field as fertilizer or discharged as surface water. In both scenarios, the effluent should be treated prior to being recycled but, in most cases, treatment consists of only decantation and sometimes in the decay of organic matter in stabilizing lagoons. In the case of thermal pollution of water used in the cooling of furnaces and other equipment in the distilleries, water is not always properly cooled before being mixed with other effluents and discharged into water bodies.

Finally, the most important liquid effluent associated with the ethanol industry is vinasse, which is produced during fermentation [25]. In general, for each L of ethanol produced, 10 to $13 \mathrm{~L}$ of vinasse is generated [26]. Vinasse has a BOD of $175,000 \mathrm{mg} \cdot \mathrm{L}^{-1}$, and high concentrations of $\mathrm{K}$ and $\mathrm{N}$ [26]. Therefore, discharging vinasse in water bodies is illegal in Brazil, so most of the vinasse is mixed with liquid effluents described above and ap- 
plied in sugarcane fields as fertilizer in a process called "fertirrigation". According to Luz [26], mills in São Paulo generally apply $300 \mathrm{~m}^{3}$ of vinasse ha ${ }^{-1}$. Unfortunately, accidental and illegal spills in water bodies are common.

\section{Material and Methods}

We estimated the water use by sugar mills in São Paulo using data from the Department of Water and Energy (DAEE), which is responsible for granting the industrial sector permission to withdraw water from rivers, lakes, reservoirs or groundwater. In Brazil, water resources belong to the state, therefore, each mill in São Paulo is required to request permission to withdraw water from water resources, which is granted or denied depending on the water level and seasonal conditions. In addition, mills must explicitly declare how much of the water withdrawn will be returned to the water source. The consumptive water use was estimated by the difference between the amount of water withdrawn and the amount of water returned to the water source.

The DAEE database contains the water withdrawals expressed in $\mathrm{m}^{3} \cdot \mathrm{h}^{-1}$, and the number of hours and days per month that water is pumped from streams, rivers or groundwater. In order to convert the water withdrawals from $\mathrm{m}^{3} \cdot \mathrm{h}^{-1}$ to $\mathrm{m}^{3} \cdot \mathrm{yr}^{-1}$, we use the following equation:

$$
W W y\left(\mathrm{~m}^{3} \cdot \mathrm{yr}^{-1}\right)=W W h\left(\mathrm{~m}^{3} \cdot \mathrm{h}^{-1}\right) \times h \times d \times m
$$

where, WWy is the water withdraw expressed in $\mathrm{m}^{3} \cdot \mathrm{yr}^{-1}$, $W W h$ is the water withdraw expressed in $\mathrm{m}^{3} \cdot \mathrm{h}^{-1}, h$ is the number of hours, $d$ is the number of days per month, and $m$ is the number of months that water is retrieved from a water source. As the harvesting season, and consequently, ethanol and sugar production occurs during approximately 8 months per year, we assumed in the equation above a $m=8$.

According to state regulations in São Paulo, all mills were obligated to renew their license by 2008 , hence, the DAEE database used in this study is the most recent available. We further refined the database by including only mills with licenses valid from 2003 to 2008 and excluding mills no longer in operation. We also excluded mills that had a license to withdraw water in 2008 but were not yet fully operational. Overall, our final database included a total of 140 operational mills in São Paulo. For 96 of these mills there was also available the amount of sugarcane harvested in the 2007-2008 season [27]. We estimated the water use expressed as $\mathrm{m}^{3} \cdot \operatorname{ton}^{-1}$ by summing the water withdraw of these 96 mills and dividing by the total amount of sugarcane harvested by these mills.

For any given mill, the water volume requested is not necessarily the volume withdrawn de facto. Consequently, we denote that the values for water withdrawals obtained from DAEE are actually potential water withdraws. At the same time, the values from DAEE are unlikely to be very different from the actual withdraw values because mills now have to pay the state for the use of water from rivers, reservoirs and groundwater, and the charge is based on the volume requested and not on the actual withdraw. In the Piracicaba River basin, for instance, which is one of the most important regions of sugarcane production in the state; this charge is already in effect, which has prompted the mills to renew their licenses for water withdrawals.

For each liter of ethanol that is produced in Brazil, 10 to $13 \mathrm{~L}$ of vinasse is produced, as mentioned above [26]. Thus, in order to estimate the volume of vinasse produced in São Paulo during the 2007-2008 harvest season, we multiplied the estimated volume of ethanol produced by mills in the state (approximately 12 billion liters) by a factor of 10 [22].

Vinasse has an average biological oxygen demand (BOD) of approximately $18 \mathrm{~kg} \cdot \mathrm{m}^{-3}$ [26]. Therefore, by multiplying this number by the total volume of vinasse produced in the harvest season, we estimated the total annual organic load of vinasse from which we calculated the average daily rate.

Application of vinasse to sugarcane crops (fertirrigation) in São Paulo varies from 200 to $300 \mathrm{~m}^{-3} \cdot$ ha [26]. Assuming an intermediate application rate of $250 \mathrm{~m}^{-3} \cdot$ ha, we determined the total amount of N, P and $\mathrm{K}$ added as vinasse applied to sugarcane fields in São Paulo by multiplying the application rate by average concentrations of $\mathrm{N}\left(375 \mathrm{mg} \cdot \mathrm{L}^{-1}\right), \mathrm{P}\left(60 \mathrm{mg} \cdot \mathrm{L}^{-1}\right)$ and $\mathrm{K}\left(2000 \mathrm{mg} \cdot \mathrm{L}^{-1}\right)$ in vinasse [28].

We are fully aware that the quality of vinasse and the quantity of ethanol produced varies widely among mills. Accordingly, in order to avoid overestimations, we used average values of nutrient content in vinasse, and the lowest estimates of vinasse production $\mathrm{L}^{-1}$ of ethanol. We also used average figures for the volume of vinasse applied to the field as fertilizer.

\section{Results}

Water use-Based on data from the 140 mills that we selected from the DAEE database, we estimated that the volume of water withdrawn in the 2007-2008 harvest season was approximately 800 million $\mathrm{m}^{3}$, and the consumptive use was approximately 440 million $\mathrm{m}^{3}$; consequently approximately 360 million $\mathrm{m}^{3}$ returned to water bodies. From this total, surface water, mainly from rivers and streams, contributed $96 \%$ and groundwater for the remaining $4 \%$. Part of the water that does not return to surface waters is lost in evaporation during the cooling process or is mixed with vinasse and applied to the field [19]. Eventually the water in vinasse returns to the atmosphere via evaporation or drain into the soil. 
In 2008, the total water use in São Paulo, which included the use by different industrial sectors and for domestic consumption, was about 10 billion $\mathrm{m}^{3}$, and approximately 3 billion $\mathrm{m}^{3}$ for the industrial sector only. Therefore, consumptive water use by the sugarcane industry in 2007-2008 (440 million $\mathrm{m}^{3}$ ) was equivalent to $4 \%$ of the total water consumed in the state in 2008 , and equivalent to approximately $15 \%$ of the volume consumed by industries (Table 1).

Using geographical coordinates of water withdraw sites from the DAEE database, we produced a hydrological map with the withdraw sites for São Paulo (Figure 1). By cross examining site locations and river order using GIS, we determined that almost $50 \%$ of the water withdraw sites are located in first-order streams. Only $16 \%$ of the sites are located in third or higher order streams and rivers (Table 2).

When we evaluated water withdraw on a watershed basis, we observed that the Mogi-Guaçu and TurvoGrande watersheds have the highest withdraw values, and that the sugarcane industry accounted for approximately $15 \%$ of the total water withdrawn in each basin, and for $30 \%$ and $60 \%$ of the volume used by the industrial sector in the Mogi-Guaçu and Turvo-Grande watersheds, respectively (Table 1).

Based on the total amount of sugarcane harvested by 96 mills in the 2007-2008 harvest-year and on the total volume of water withdrawn by these mills during the same period, we estimated that water consumption ton ${ }^{-1}$ of sugarcane produced was approximately $1.53 \mathrm{~m}^{3} \cdot \mathrm{ton}^{-1}$. Therefore, assuming that, on average, 1 ton of sugarcane yields $83 \mathrm{~L}$ of ethanol [22], we calculated that about $18 \mathrm{~L}$ of water was used to produce $1 \mathrm{~L}$ of ethanol.

Liquid Effluents-Assuming that the 2007-2008 harvest season in São Paulo produced approximately 12 million $\mathrm{m}^{3}$ of ethanol [22], we estimated that approximately 120 million $\mathrm{m}^{3}$ of vinasse was produced. This volume of vinasse potentially yields about 3 billion $\mathrm{kg}$ BOD during the harvest season or 8 million $\mathrm{kg} \cdot \mathrm{BOD} \cdot \mathrm{d}^{-1}$. In addition, vinasse has relatively high concentrations of nutrients and adds about 74,13 , and $440 \mathrm{~kg} \cdot \mathrm{ha}^{-1}$ of N, P and $\mathrm{K}$, respectively, to soils and, potentially, to groundwater annually.

\section{Discussion}

According to our estimates, approximately 800 million $\mathrm{m}^{3}$ of water was withdrawn from São Paulo water resources for use in sugarcane mills in the 2007-2008 harvest year, and approximately 440 million $\mathrm{m}^{3}$ was effectively consumed by mills (consumptive use). This volume of consumptive use represents $15 \%$ of the industrial consumptive use but only $4 \%$ of the total consumptive use in the state (Table 1), which may be considered a relatively small percentage [29]. However, in specific watersheds, like Mogi-Guaçu, Turvo-Grande, and Piracicaba, where there is a limited renewable water resources, the rate of water withdraw for use by sugarcane mills may create a serious stress to water resources on a regional scale (Table 1).

Water managers in São Paulo consider water use to be at a critical level when the ratio between the total amount used and $\mathrm{Q}_{7,10}$ (minimum weekly discharge over a 10year return period) is higher than $50 \%$ (Table 1). Table 1 shows that about half of the major watersheds in São Paulo are already at or above this critical level for water use. Moreover, our analyzes indicate that in the watersheds where water use by sugarcane mills is high, the ratio of total water use and $\mathrm{Q}_{7,10}$ are the highest, as is the case for the Mogi-Guaçu and the Turvo-Grande watersheds (Table 1). These watersheds have ratios of total water use to $\mathrm{Q}_{7,10}$ of $84 \%$ and $62 \%$, respectively, and the withdraw of water for sugarcane processing is likely to be a key player in the future of water management in these watersheds.

Water withdraws per amount of harvested sugarcane found here $\left(1.53 \mathrm{~m}^{3} \cdot \operatorname{ton}^{-1}\right)$ was similar to the value found by Elia Neto [24]; and, more important is the fact that this value have decreased ten times in the last 40 years, from $15 \mathrm{~m}^{3} \cdot \operatorname{ton}^{-1}$ to the present value [30]. In spite of this increase in the efficiency of water use, it's important that the sugarcane industry continues to work on solutions to minimize such use [14,31]. For instance, according to Dedini S/A [32], a company devoted to building sugar and ethanol industrial plants, technology that allow mills to generate water extracted from sugarcane is already available and can potentially decrease the consumptive use of water by sugarcane mills to almost zero. This gain in water use efficiency is especially important because most of the water is withdrawn by the sugarcane industry from 1st order streams and small rivers (Figure 1), which are already under intensive pressure due to the heavy loads of untreated domestic sewage [33-35], and increasing non-point sources of pollution from agricultural $[36$, 37].

However, while the water use issue may be relatively easy to resolve, many water resource scientists believe that the major threat from the sugarcane ethanol industry is from industrial effluents such as vinasse that cause severe water pollution [19].

We estimated that almost 120 million $\mathrm{m}^{3}$ of vinasse were produced in São Paulo in the 2007-2008 harvest season. Until the mid 1980s, most of the vinasse was dumped untreated in rivers and streams [14]. Today, there are strict laws that regulate the use of these industrial effluents in Brazil to prevent pollution in aquatic bodies. Accordingly, most of the vinasse produced is mixed with other effluents of the sugarcane industry and used as fertilizer in a process called "fertirrigation" and provide about $74 \mathrm{~kg} \cdot \mathrm{N} \cdot \mathrm{ha}^{-1}, 13 \mathrm{~kg} \cdot \mathrm{P} \cdot \mathrm{ha}^{-1}$, and 440 
Table 1. Water withdraw by the sugarcane industry in major watersheds of the state of São Paulo with respective information about their area, population, and the relative proportion of the sugarcane industry withdraw in relation to the industrial water use and in relation to the total water use of each basin. Etanol/Q7, 10 and Total/Q7, 10 represents the ratio between the water withdraw by the sugarcane industry in a specific basin and the total withdraw of that basin in relation to the minimum weekly discharge over a 10 -year return period $(Q 7,10)$ of that basin. The water use is considered critical in watersheds that the ratio Total/Q7, 10 are higher than $50 \%$ (indicated by ${ }^{* *}$ ).

\begin{tabular}{|c|c|c|c|c|c|c|c|c|}
\hline \multirow{2}{*}{ Watershed } & Watershed & Area & Population & Water withdraw & Industrial & Total & Cane $/ \mathrm{Q}_{7,10}$ & Total $/ \mathrm{Q}_{7,10}$ \\
\hline & $\operatorname{code}^{*}$ & $\mathrm{~km}^{2}$ & & $\mathrm{~m}^{3} \cdot$ year $^{-1}$ & \multicolumn{4}{|c|}{$\%$} \\
\hline Mogi-Guaçu & 9 & 15,004 & $1,463,953$ & $197,492,817$ & 29 & 14 & 13 & $84^{* *}$ \\
\hline Turvo-Grande & 15 & 15,925 & $1,179,425$ & $101,613,866$ & 63 & 15 & 10 & $62^{* *}$ \\
\hline Tietê-Jacaré & 13 & 11,749 & $1,421,415$ & $71,572,105$ & 28 & 7 & 4 & $57^{* *}$ \\
\hline Piracicaba & 5 & 14,178 & $4,912,256$ & $67,903,151$ & 11 & 4 & 4 & $95^{* *}$ \\
\hline Baixo-Tietê & 19 & 15,588 & 701,324 & $58,518,808$ & 73 & 8 & 6 & $68^{* *}$ \\
\hline Pardo & 4 & 8993 & $1,068,876$ & $53,318,130$ & 26 & 6 & 5 & $69^{* *}$ \\
\hline Baixo Grande-Pardo & 12 & 7249 & 337,106 & $43,695,535$ & 45 & 7 & 5 & $62^{* *}$ \\
\hline Sorocaba-Médio Tietê & 10 & 11,829 & $1,826,148$ & $38,808,208$ & 47 & 9 & 8 & $82^{* *}$ \\
\hline Aguapeí-Peixe & $20-21$ & 13,196 & 926,563 & $29,393,379$ & 55 & 6 & 1 & 22 \\
\hline Sapucaí Mirim-Grande & 8 & 9125 & 685,440 & $28,743,671$ & 21 & 3 & 3 & $91^{* *}$ \\
\hline Tietê-Batalha & 16 & 13,149 & 549,094 & $27,963,869$ & 57 & 7 & 2 & 32 \\
\hline Alto Paranapanema & 14 & 22,689 & 780,145 & $27,557,152$ & 29 & 2 & 1 & 29 \\
\hline Médio Paranapanema & 17 & 16,749 & 653,213 & $25,234,719$ & 23 & 5 & 1 & 20 \\
\hline Pontal do Paranap. & 22 & 12,395 & 431,255 & $18,442,680$ & 11 & 7 & 1 & 19 \\
\hline São José dos Dourados & 18 & 6783 & 234,422 & $3,028,895$ & 55 & 5 & 1 & 19 \\
\hline State of São Paulo & & 248,209 & $41,034,426$ & $793,286,986$ & 21 & 6 & 3 & 47 \\
\hline
\end{tabular}

* Location of each watershed is found according to each watershed code in Figure 1.

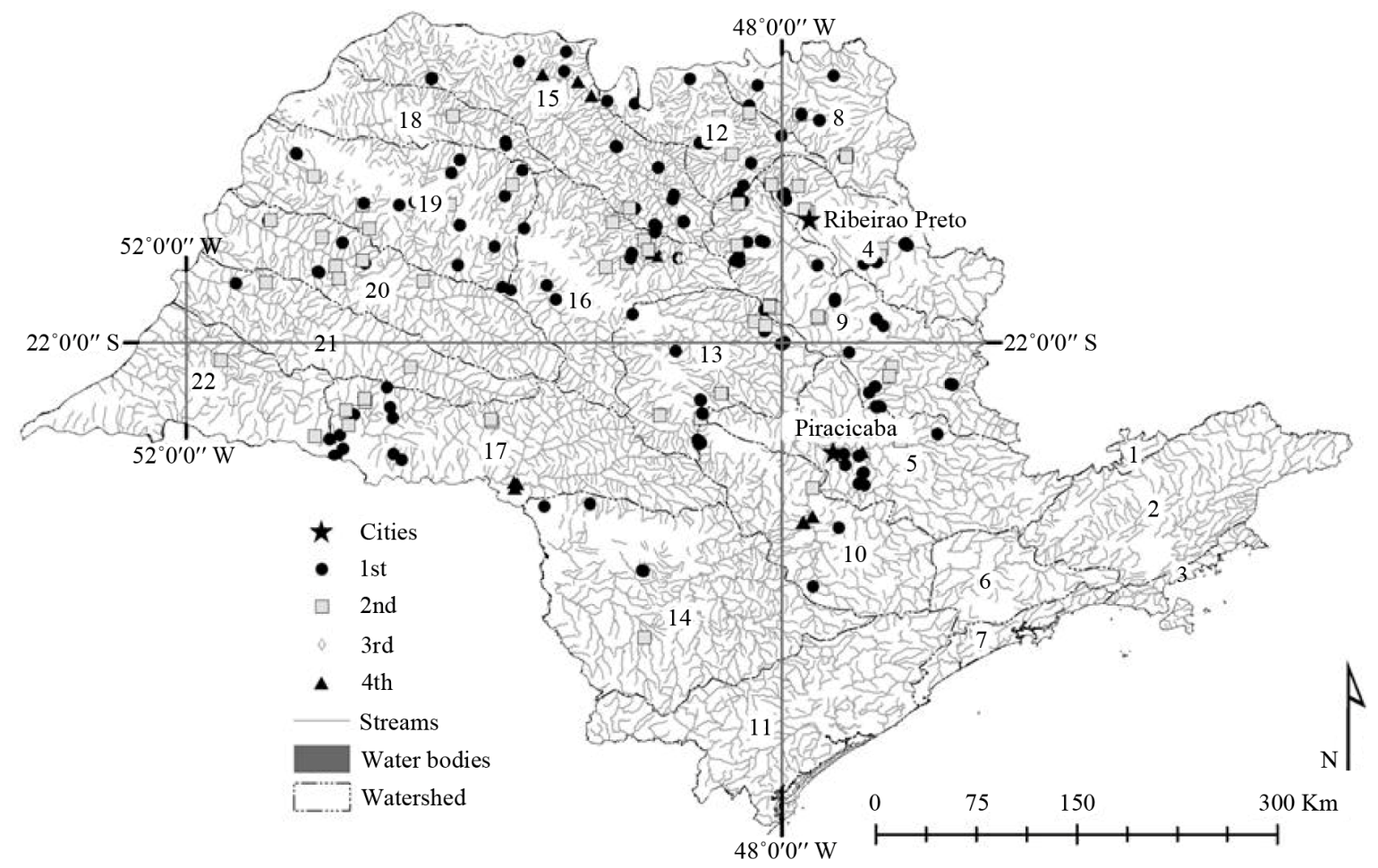

Figure 1. Hydrography in the state of São Paulo and water capitation sites obtained from DAEE database. Numbers indicate watersheds of the State of São Paulo (see Table 2). 
Table 2. Percentage of water withdraw by sugar-ethanol mills of the state of São Paulo according to the river order.

\begin{tabular}{ccc}
\hline Water sources & Number & Percentage \\
\hline river 1st order & 151 & $49 \%$ \\
river 2nd order & 56 & $18 \%$ \\
river 3rd order & 35 & $11 \%$ \\
river 4th order & 14 & $5 \%$ \\
Reservoirs & 50 & $16 \%$ \\
\hline
\end{tabular}

$\mathrm{kg} \cdot \mathrm{K} \cdot \mathrm{ha}^{-1}$ to sugarcane fields annually.

The use of these effluents in sugarcane plantations has significantly alleviated the pressure on aquatic ecosystems in recent decades. However, pollution problems have not been resolved, mainly because vinasse is produced in very high quantities and is difficult to handle due to its high temperatures, low $\mathrm{pH}$, and corrosive effects. In addition, in order to be applied to the field, vinasse must to be transported for long distances from its origin of production (up to $20-30 \mathrm{~km}$ ). The logistics for this kind of transfer vary from mill to mill, but occur mainly through pipelines or trucks, when vinasse is then applied by gravity to irrigation channels.

The transfer of vinasse through pipelines, trucks and irrigation channels increases the chances of accidental spills, and threats rivers and streams located near the mills. It is difficult to quantify how frequent accidental spills occur because they are illegal and, therefore, not always reported. Therefore, in order to obtain at least an idea of the frequency of these accidents, we searched for data on fines for vinasse spills in regional offices of the São Paulo State Environmental Agency (CETESB) responsible for monitoring fifteen mills located in the eastern portion of the state for the period of 2003-2008. In the surveyed period, we found eleven accounts of spills of untreated industrial effluent to water bodies, most involving vinasse. Therefore, regardless the limited number of mills included in this survey (15), which was less than $10 \%$ of the number of mills operating in São Paulo, we confirmed that accidents do occur and that they are rather frequent.

Besides the impact to aquatic systems, more recently, the excessive use of vinasse in agricultural areas located near mills to reduce transportation costs has become a concern to water resources managers and environmentalists due to soil and groundwater contamination by $\mathrm{K}$. This concern led CETESB to establish a law in the beginning of 2005 requiring that in areas where soil $\mathrm{K}$ concentrations higher than $5 \%$ of the soil cation exchange capacity, the volume of vinasse applied cannot exceed the amount required to replenish the $\mathrm{K}$ uptake by the sugarcane $(185 \mathrm{~kg})$ [38]. Therefore, in the near future, several areas growing sugarcane and located near mills will not be allowed to have vinasse application. This will pre- sent the mills with an operational problem as the cost of vinasse transportation will continue to increase since the mills need to reach areas increasingly farther away from their operation site.

Considering that vinasse spills pose a significant threat to aquatic ecosystems [39] and that K-enrichment of soil and groundwater in areas heavily fertilized with vinasse is likely to increase together with the cost of transporting vinasse to more remote areas, we believe that vinasse treatments aiming to significantly decrease the volume of this byproduct generated is essential to guarantee the sustainability of sugarcane ethanol production in Brazil. Anaerobic treatment of vinasse with the concomitant production of biogas could be one of the most viable solutions [25]. More recently, studies have shown that by increasing the alcohol content of the sugarcane extract during the fermentation process, the volume of vinasse produced decreases by $50 \%$. This change in the fermentation process has been already tested at the industrial scale in two mills in São Paulo (Henrique Vianna de Amorim, personal communication, 2009) and may greatly improve the vinasse waste production problem.

\section{Conclusions}

Ethanol from sugarcane has several advantages over other types of biofuels. However, although water used by mills has decreased in recent decades, the unprecedented expansion of the sugarcane area that has occurred in Brazil in recent years suggests that the water withdrawn by mills needs to decrease even further to alleviate regional stress on water resources and the pressure on small streams from which most of the water is taken. This is especially important in the state of São Paulo, where several river basins are already suffering from water scarcity due to a high demand and decreasing water quality. In this respect, it is important to point out that technological solutions already exist as one of the largest mill developers and producers of Brazil has developed mills that require almost no blue water for their operation. By combining water recycling solutions and water extracted from the sugarcane plant, they claim that blue water use can decrease to insignificant levels.

However, even if water use decreases drastically, pollution problem associated with industrial effluent, mainly vinasse, can be still a major problem for the ethanol industry if industrial practices are not improved. The use of vinasse as fertilizer (fertirrigation) that began two decades ago significantly reduced pressure on aquatic ecosystems. Yet, because the volume of vinasse produced is so large, and the handling and transportation of this vinasse are difficult, accidental spillage into rivers and streams is common. Moreover, the fertirrigation technique is causing $\mathrm{K}$ pollution in soil and groundwater in areas near mills, which have received excessive amounts 
of vinasse. Therefore, the sustainability of sugarcane ethanol production in Brazil can only be guaranteed if water management includes not only the reduction of water use but also the treatment of industrial effluents.

\section{REFERENCES}

[1] FAO, "The State of Food and Agriculture. Biofuels: Prospects, Risks and Opportunities," FAO, Rome, 2008.

[2] R. W. Howarth, S. Bringezu, L. A. Martinelli, D. Massem, R. Santoro and O. Sala, "Introduction: Biofuels and the Environment in the 21st Century," In: R. Howarth and G. Bringezu, Eds., Biofuels Environmental Consequences and Interactions with Changing Land Use, Cornell University, Ithaca, 2009, pp. 15-36.

http://cip.cornell.edu/biofuels/

[3] N. H. Ravindranatha, R. Manuviea, J. Fargione, J. G. Canadell, G. Berndes, J. Woodse, H. Watson and J. Sathayeh, "Greenhouse Gas Implications of Land Use and Land Conversion to Biofuel Crops," In: R. Howarth and S. Bringezu, Eds., Biofuels Environmental Consequences and Interactions with Changing Land Use, Cornell University, Ithaca, 2009, pp. 111-125. http://cip.cornell.edu/biofuels/

[4] M. F. Neves and M. A. Conejero, "Sistema Agroindustrial da Cana: Cenários e Agenda Estratégica," Economia Aplicada, Vol. 11, 2007, pp. 587-604. doi:10.1590/S1413-80502007000400007

[5] M. A. F. D. Moraes, "O Mercado de Trabalho da Agroindústria Canavieira: Desafios e Oportunidades," Economia Aplicada, Vol. 11, 2007, pp. 605-619. doi:10.1590/S1413-80502007000400008

[6] D. J. Connor and C. G. Hernandez, "Crops for Biofuel: Current Status and Prospects for the Future," In: R. Howarth and S. Bringezu, Eds., Biofuels Environmental Consequences and Interactions with Changing Land Use, Cornell University, Ithaca, 2009, pp. 65-80. http://cip.cornell.edu/biofuels/

[7] F. Johnson, "Sugarcane Resources in Southern Africa," Tiempo: Global Warming and the Third World, Vol. 35, 2000, pp. 1-4.

[8] L. A. Martinelli and S. Filoso, "Expansion of Sugarcane Ethanol Production in Brazil: Environmental and Social Challenges," Ecological Applications, Vol. 18, No. 4, 2008, pp. 885-898. doi:10.1890/07-1813.1

[9] I. C. Macedo, J. E. A. Seabra and J. E. A. R. Silva, "Green House Gases Emissions in the Production and Use of Ethanol from Sugarcane in Brazil: The 2005/2006 Averages and Prediction for 2020," Biomass and Bioenergy, Vol. 32, No. 7, 2008, pp. 582-595. doi:10.1016/j.biombioe.2007.12.006

[10] M. A. D'Agosto and S. K. Ribeiro, “Assessing Total and Renewable Energy in Brazilian Automotive Fuels. A life Cycle Inventory (LCI) Approach," Renewable and Sustainable Energy Reviews, Vol. 13, No. 6-7, 2009, pp. 1326-1337. doi:10.1016/j.rser.2008.08.008

[11] D. Pimentel and T. W. Patzek, "Ethanol Production: Energy and Economic Issues Related to US and Brazilian
Sugarcane," In: D. Pimentel, Ed., Biofuels, Solar and Wind as Renewable Energy Systems, Springer, Ithaca, 2008, pp. 357-371. doi:10.1007/978-1-4020-8654-0 14

[12] A. R. Ometto, M. Z. Hauschild and W. N. L. Roma, "Lifecycle Assessment of Fuel Ethanol from Sugarcane in Brazil," The International Journal of Life Cycle Assessment, Vol. 14, No. 3, 2009, pp. 236-247. doi:10.1007/s11367-009-0065-9

[13] M. E. D. de Oliveira, B. E. Vaughan and E. J. Rykiel Jr., "Ethanol as Fuel: Energy, Carbon Dioxide Balances, and Ecological Footprint," Bioscience, Vol. 55, No. 7, 2005, pp. 593-602.

doi:10.1641/0006-3568(2005)055[0593:EAFECD]2.0.CO ;2

[14] J. Goldemberg, S. T. Coelho and P. Guardabassi, "The Sustainability of Ethanol Production from Sugarcane," Energy Policy, Vol. 36, No. 6, 2008, pp. 2086-2097. doi:10.1016/j.enpol.2008.02.028

[15] A. Y. Hoekstra, A. K. Hung, A. Y. Hoekstra and P. Q. Hung, "Globalization of Water Resources: International Virtual Water Flows in Relation to Crop Trade," Global Environmental Change, Vol. 15, No. 1, 2005, pp. 45-56. doi:10.1016/j.gloenvcha.2004.06.004

[16] A. Y. Hoekstra and A. K. Chapagain, "Water Footprints of Nations: Water Use by People as a Function of Their Consumption Pattern," Water Resources Management, Vol. 21, No. 1, 2007, pp. 35-48. doi:10.1007/s11269-006-9039-x

[17] M. Falkenmark and J. Rockström, "Balancing Water for Humans and Nature. The New Approach in Ecohydrology," Earthscan, London, 2004.

[18] V. Barbieri, "Medidas e Estimativas de Consumo Hídrico em Cana-de-Açúcar (Saccharum spp)," Ph.D. Dissertation, Universidade de São Paulo, Piracicaba,1981.

[19] G. Berndes, "Bioenergy and Water-The Implications of Large-Scale Bioenergy Production for Water Use and Supply," Global Environmental Change, Vol. 12, No. 4, 2002, pp. 253-271. doi:10.1016/S0959-3780(02)00040-7

[20] C. de Fraiture, M. Giordano and Y. Liao, "Biofuels and Implications for Agricultural Water Uses: Blue Impacts of Green Energy," Water Policy, Vol. 10, No. S1, 2008, pp. 67-81. doi:10.2166/wp.2008.054

[21] C. de Fraiture and G. Berndes, "Biofuels and Water," In: R. Howarth and S. Bringezu, Eds., Biofuels Environmental Consequences and Interactions with Changing Land Use, Cornell University, Ithaca, 2009, pp 139-153. http://cip.cornell.edu/biofuels/

[22] Companhia Nacional de Abastecimento Perfil do Setor do Açúcar e do Álcool no Brasil, "Situação Observada em Novembro de 2007," Ministério da Agricultura, Pecuária e Abastecimento, Brasília, 2008.

[23] A. Elia Neto, "Água na Indústria da Cana de Açúcar. Workshop Projeto PPP: Aspectos Ambientais da Cadeia do Etanol de Cana de Açúcar," Centro Tecnológico Canavieiro, Piracicaba, 2008.

http://www.apta.sp.gov.br/cana

[24] A. Elia Neto, "Captação e Uso de Água no Processamento da Cana de Açúcar,” In: I. C. Macedo, Ed., Doze Estudos 
Sobre a Agroindústria da Cana-de-Açúcar no Brasil e a sua Sustentabilidade, Unica, São Paulo, 2005.

[25] A. C. Wilkie, K. J. Riedesel and J. M. Owens, "Stillage Characterization and Anaerobic Treatment of Ethanol Stillage from Conventional and Cellulosic Feedstocks," Biomass and Bioenergy, Vol. 19, No. 2, 2000, pp. 63-102. doi:10.1016/S0961-9534(00)00017-9

[26] P. H. C. Luz, "Métodos de Utilização e Aplicação de Vinhaça," Workshop Tecnológico sobre Vinhaça, Pirassununga, 2008.

[27] ÚNICA, 2008.

http://www.unicadata.com.br/historico-de-producao-e-mo agem.php?idMn $=32 \&$ tipoHistorico $=4 \&$ acao $=$ visualizar $\& \mathrm{i}$ dTabela $=1325 \&$ safra $=2007 \% 2$ F2008\&estado $=S P$

[28] A. Elia Neto and T. Nakahodo, "Caracterização FísicoQuímica da Vinhaça," Relatório Técnico da Seção de Tecnologia de Tratamento de Água do Centro de Tecnologia Copersucar, Piracicaba, 1999.

[29] São Paulo-Conselho Estadual de Recursos Hídricos, "Plano Estadual de Recursos Hídricos: 2004/2007 Resumo," DAEE, São Paulo, 2006.

[30] ANA-FIESP-UNICA-Agência Nacional de Águas/Federação das Indústrias do Estado de São Paulo/União da Indústria da Cana-de-Açúcar: Centro de Tecnologia Canavieira, 2009.

http://www.fiesp.com.br/ambiente/downloads/publicagua b.pdf

[31] R. C. Cerqueira Leite, M. R. L. V. Leal, L. A. B. Cortez, W. M. Griffin and M. I. G. Scandiffio, "Can Brazil Replace $5 \%$ of the 2025 Gasoline World Demand with Ethanol?” Energy, Vol. 34, No. 5, 2009, pp. 655-661. doi:10.1016/i.energy.2008.11.001

[32] http://www.dedini.com.br/pt/realese/010708c.pdf

[33] L. A. Martinelli, A. Krusche, R. L. Victoria, P. B. Camargo, M. C. Bernardes, E. S. Ferraz, J. M. Moraes and M. V. Ballester, "Effects of Sewage on the Checimal Composition of Piracicaba River, Brazil," Water, Air and Soil Pollution, Vol. 110, No. 1-2, 1999, pp. 67-79. doi:10.1023/A:1005052213652
[34] M. H. B. Daniel, A. A. Montebello, M. C. Bernardes, J. P. H. B. Ometto, P. B. Camargo, A. V. Krusche, M. V. Ballester, R. L. Victoria and L. A. Martinelli, "Effects of Urban Sewage on Dissolved Oxygen, Dissolved Inorganic Carbon and Organic Carbon, and Electrical Conductivity of Small Streams along a Gradient of Urbanization in the Piracicaba River Basin," Water, Air, and Soil Pollution, Vol. 136, No. 1-4, 2002, pp. 189-206. doi:10.1023/A:1015287708170

[35] J. D. Groppo, J. M. Moraes, C. E. Beduschi, A. M. Genovez and L. A. Martinelli, "Trend Analysis of Water Quality in Some Rivers with Different Degrees of Development within the São Paulo State, Brazil," River Research and Applications, Vol. 24, No. 8, 2008, pp. 10561067. doi:10.1002/rra.1091

[36] J. P. H. B. Ometto, L. A. Martinelli, M. V. Ballester, A. Gessner, A. Krusche, R. L. Victoria and M. Williams, "Effects of Land Use on Water Chemistry and Macroinvertebrates in Two Streams of the Piracicaba River Basin, Southeast Brazil," Freshwater Biology, Vol. 44, No. 2, 2000, pp. 327-337. doi:10.1046/j.1365-2427.2000.00557.x

[37] S. Filoso, L. A. Martinelli, M. R. Williams, L. B Lara, A. Krusche, M. V. Ballester, R. Victoria and P. B. Camargo, "Land Use and Nitrogen Export in the Piracicaba River Basin, Southeast Brazil," Biogeochemistry, Vol. 65, No. 3, 2003, pp. 275-294. doi:10.1023/A:1026259929269

[38] CETESB - Companhia de Tecnologia de Saneamento Ambiental, "Norma Técnica-P4.231-Vinhaça Critérios e Procedimentos para Aplicação no Solo Agrícola," 2005. http://www.cetesb.sp.gov.br/Tecnologia/camaras/P4_231. pdf

[39] G. Gunkel, J. Kosmol, M. Sobral, H. Rohn, S. Montenegro and J. Aureliano, "Sugar Cane Industry as a Source of Water Pollution-Case Study on the Situation in Ipojuca River, Pernambuco, Brazil," Water, Air, and Soil Pollution, Vol. 180, No. 1-4, 2007, pp. 261-269. doi:10.1007/s11270-006-9268-X 